\title{
The Ethics and Moral status under the rule of law of Prosecuters ${ }^{1}$
}

Talat Faruq Lone

\section{ABSTRACT}

Ethical training could contribute a lot for professional development. Law Prosecutors as ethical agents could play their role in many ways. Training of Prosecutors, besides professional requirements, includes education teaching them the importance of fiduciary relationship of client.

Keywords: Ethics. Moral. Rule of Law. Prosecutors.

"Morality matters, not just because it should govern our personal behavior and the way we treat others. It should provide the context in which all affairs are conducted and Nations governed".

Roger Trigg

\section{INTRODUCTION}

Ethics is a branch of philosophy which seems to address questions about morality, such as what the fundamental semantic, ontological and epistemic nature of ethics or morality is (meta-ethics), how moral values should be determined, (normative ethics), how a moral outcome can be achieved in specific situation, (applied ethics), how moral capacity or moral agency develops and what its nature is, (moral psychology, and what moral values people actually abide by,

1 Data de recebimento: 17/07/2018. Data de Aceite: 21/09/2018.

2 Master of Law, LL.M, from Karachi University, Pakistan PK Member, International Association of Prosecutors. E-mail: rtn_talatfaruqlone@hotmail.com 
(descriptive ethics). Ethics is defined as:

a. A set of principles of right conduct.

b. A theory or a system of moral values.

The study of the general nature of morals and of the specific moral choices to be made by a person: moral philosophy.

The rules or standards governing the conduct of a person or the members of a profession: medical ethics.

Ethics is defined as motivation based on ideals of right and wrong and the philosophical study of moral values and rules.

Ethics word origin from Greek thinks, ethical, from those, character.

The term "morality comes from Latin moralitas manner, character, "proper behavior". It has three principal meanings. In its first, descriptive usage, morality means a code of conduct which is held to be authoritative in matters of right and wrong. Morals are created by and define society, philosophy, religion or individual conscience. An example of the descriptive usage could be "common conceptions of morality have changed significantly over time."

In its second, normative and universal sense, morality refers to an ideal code of conduct, one which would be espoused In preference to alternatives by all rational people, under specified conditions. In this "prescriptive" sense of morality as opposed to the above stated "descriptive" sort of sense, moral value judgments such as "murder is immoral" are made. To deny 'morality' in this sense is a position known as moral skepticism, in which the existence of objective moral "truths" is rejected.

In this third usage, 'morality' is synonymous with ethics, the systematic philosophical study of the moral domain.

Morality and Ethics intrinsically are abstract normative ought which are expected to be followed by people living in society. These are the socially agreed value expectations which any civilized society hopes from their individuals. According to sociological philosophical 
and historical schools of thought, morality provides the justification for the Laws in society.

\section{DEVELOPMENT}

The Rule of Law is important, especially to the extent that it checks possible abuse of authority by the executive. It has the negative impact of detracting from a more important aspect which is, according to the Supreme Court Bar Association's, under which the Supreme Court ethical Bar Association was formed is to maintain higher professional standards of probability and integrity amongst its Prosecutors members and "check and eradicate unprofessional practices".

Ethical standards for Prosecutors have been of concern in the subcontinent at least since the British Royal Charter of 1774, established by the Supreme Court of Judicature. Before this the subcontinent had experienced sophisticated secular legal system under the Mauryas (321-185 BC) and the Mughuls (16th -19th Centuries); however, it had neither had nor felt the need for an organized legal profession of Prosecutors as most supplicants either pleaded their cases in person or through trusted relatives, friends, or patrons. Prosecutors have the duty to represent the state cases with honesty.

The Supreme Court and the High Courts recognition, wealth and prestige to the legal profession of prosecutors and with it the need to ensure that only qualified prosecutors of character and integrity could appear before the Courts.

There is no denying that without effective investigation. An effective prosecution cannot follow. An effective investigation is a precedent condition, which provides a concrete base to effective prosecution.

The prosecutors are supposed to supervise the overall prosecution but rarely do so. The prosecutors should examine the draft report and direct the deficiencies of evidence therein need to be attended to. Public Prosecutors must also play an effective role in analyzing, 
examining and evaluating the evidence collected by the investigation agency, but do not do so, which amounts to a glaring flaw of procedure. The prosecutor is a watch-dog and the leading character of all overall prosecutions and should implement the enshrined principles of effective prosecution.

For successful prosecutions, prosecutors ought to consider the following principles enumerated here under:

* Whether the provisions of Code of Criminal Procedure has been violated. If so prosecutors must know, how to make the necessary rectifications;

* If the F.I.R. contains technical flaws, how to streamline the case during the investigation;

* Whether the investigation officer conducted the investigation under the law. If not, the prosecutor should know how the case might be improved upon;

* Verify il the oral, documentary and circumstantial evidence comply with the criteria laid down in the Qanun-e-Shadadt Order 1984 (with reference to law of precedents laid down by the higher courts);

* Whether the facts as reflected in the F.I.R. have been addressed in the Challan (i.e. report under Section 173 of Cr.P.C.)? If not, how to plug the loopholes;

* Whether the challan has been submitted in court within the prescribed period as laid down in Section 173 of Cr. P.C.;

* Whether the accused's defense is plausible? If not, how to highlight and rebuilt the same before the Court;

It is also observed that the investigator and the prosecutor both have become the prisoners of procedure, when they always look and try to dig for the direct evidence and do not bother to look for circumstantial evidence; although it is a well-defined principle of prudence that a conviction can also be recorded on the basis of circumstantial evidence. Article 164 of Qanun-e-Shahadat Order 1984, permits the use of modern devices and evidence detected 
thereon are admissible in evidence.

A data bank of perpetrators in respect of finger printing, blood grouping and DNA sampling, has also not been established. Modern devices like cell phones and internet could also be used.

Immediate duties of prosecutors are:

* To promote the cause of prosecution.

* To thoroughly scrutinize challans

* To ensure the observance of conditions and restrictions of codes with reference to Police rules

* To ensure the observance of High Court directions with the object of expediting decisions and preventing abuses.

* To supervise the transmission of warrants and summons and to ensure that returns of such processes are made without delay.

* To guide the Investigations Officer to remove any lacunas in order to prevent the best evidence

* To survey the pending investigations ensuring timely submission of challans in court as soon as the final report is received, to vet it and, if found not comprehensive, direct the investigation agency to resubmit it in the best manner.

* To timely prepare acquittal appeals and revision petitions wherever so required

* To prepare the cross-examination of the accused and witnesses of defense, if any

The principles of ethical dimensions regarding standard of professional responsibilities are essential for effective prosecution, including the following:

* The Prosecutors must be independent in the performance of their function and should exercise their functions free of any extraneous influences, inducements, pressures, threats or interference, direct or indirect, from any quarter or for any reason.

* The Prosecutors shall all times uphold the rule of law, the integrity of criminal justice system and the right to a fair trial. 
* He/she shall at all times respect the fundamental rights of all human persons to be held before the law and abstain from any wrongful discrimination.

${ }^{*} \mathrm{He} /$ she must not manifest by words or conduct any bias or prejudice. * Give due attention to the prosecution of crimes of corruption, abuse of power, violation of human rights and other crimes recognized by law particular offences, which may have been committed against the society and public at large.

${ }^{*} \mathrm{He} / \mathrm{she}$ shall not, through behavior and conduct compromise the actual or reasonably perceived, integrity, fairness or independence, in particular must not accept any gift, prize, loan, favor, inducement, hospitality or other benefit in relation to anything done or to be done or omitted to be done in connection with performance of duties.

* He/she shall not allow family, social or other relationship, improperly to influence his/her conduct as Prosecutor and not use or lend the prestige of his/her position as prosecutor to advance his/ her private interest or those of a member of his/her family or of anyone else, nor shall he/she convey or permit others to convey the impression that anyone is in a special position improperly to influence him/her in the performance of his/her duties.

* He/ she shall not use or disclose confidential information acquired on his/her capacity as a prosecutor for any purpose unconnected with the performance of his/her duty or the needs of justice.

${ }^{*} \mathrm{He} / \mathrm{she}$ shall remain unaffected by individual or sectional interest and public or media pressure having regard only to the public interest. ${ }^{*} \mathrm{He} / \mathrm{she}$ shall become disqualified from practising in any prosecution in which he/she is unable to act impartially or in which it may appear to a reasonable observer that such is the case.

* Prosecutors shall take reasonable steps to maintain and enhance knowledge, skills and personal qualities necessary for the proper performance of his/her duties, keeping themselves well informed of relevant regular documents. 
The Rule of Law has been defined as the "universal obligation of every civilized country. It means supremacy of Law as opposed to the arbitrary authority of the Government. This supremacy guarantees three concepts", (i) absence of arbitrary power, (ii) equality before law and (iii) rights of citizens." In that case, reference was made to Surah-e-Nisa, Verse 135, from Holy Quran as under:

O ye who believe! stand out firmly, For Justice, as witnesses, To Allah, even as against yourselves, on your parents, on your kin, and whether, It be (against) rich or poor, For Allah can best protect both, Follow not the lusts (of your hearts) last ye swerve and if ye Distant (justice) or decline to do justice, verily Allah is well-acquainted with all that ye do.

Surah-e-Rehman, Verses 7, 8 and 9 which reads as under;

And the Firmament has He Raised high, and He has set up the Balance (of justice)

Verse 8 In order that ye may Not transgress (due) balance;

Verse 9 So establish weight with justice and fall not short in the balance;

And Surah-e-Maidah, Verse 9 of the Holy Quran;

To those who believe and do deeds of righteousness hath, Allah promised forgiveness and a great reward.

While anticipating the question as to what is law, it's relevant to refer to the observation of another former Chief Justice of Pakistan, Hamoodur Rehman, J. in the case of Asma Jilani Vs. Government of Punjab and another (PLD 1972 SC 139 at 159):

So far as a Judge is concerned, if a definition is necessary, all that he has to see is that the law which he is called upon to administer is made by a person or authority legally competent to make laws and the law is capable of being enforced by the legal machinery. This, in my view, brings in the notion both of legitimacy and efficacy.

With all this in mind, it's relevant to point out how people from 
abroad look at our Superior Courts. I would like to quote here a couple of passages from the book "Judging the State" (Cambridge University Press South Asian Studies) Puaula. R. New Berg in his book observed: "The judiciary has faced difficult jurisdictional problems as it has medicated conflicts among institutions that derive their authority from diverse and sometimes incompatible resources. Equally difficult the Courts have decided that the conflicts between citizens and the State when the Government is not empowered by the citizenry, when neither rights nor obligations are clear or fully known and when punitive sanction precede reasoned Government judgment and actions. When Courts have helped to create conditions for democracy by acting as bulwarks for the citizenry against the State, the idea of democracy has taken on anti State character--a form that the Courts, themselves state institutions, find discomfiting".

\section{CONCLUSION}

From the study and observation as reproduced above, to conclude, a liaison between the prosecution and investigation agency could play a decisive role in overcoming these barriers to ensure that the perpetrators of crime can be successfully brought to justice.

As teaching is profession, ethical training in it could contribute a lot for professional development. Law Prosecutors as ethical agents could play their role in many ways. Training of Prosecutors, besides professional requirements, includes education teaching them the importance of fiduciary relationship of client and the element of confidentiality which is a trust of client in Prosecutors.

Law teachers can train Prosecutors through continuing legal and ethical training. This could increase the trust of Prosecutors, in the judicial system.

Law teachers can train personnel of law enforcing agencies so their impression and efficiency could be improved publically. 
Every Department of Prosecutors is created and executed through law. Law teachers trained in ethics could be a very good resource for the training of these prosecutors. We recommend essential continuing training, especially for Prosecutors Departments, so the efficiency could be made enhanced in a more relational context.

Working efficiency is halted due to lack of legal training in ethical context and creates an abusive work environment. This could be countered through ethical trainings by law teachers.

The lack of respect of opposite gender can give rise to harassment amongst colleagues which minimizes output of the workplace. This phenomenon could be suppressed through ethical trainings.

The lack of respect for difference of opinion give rise to irritated and less tolerant colleagues. This factor could be minimized trough ethical trainings.

It's relevant to reiterate emphatically that self improvement through training is highly recommended for Prosecutors and through them to all to build the nation.

\section{O STATOS DA ÉTICA E DA MORAL SOBRE AS REGRAS LEGAIS DO MINISTÉRIO PÚBLICO}

\section{RESUMO}

O exercício da ética pode contribuir em muito para o desenvolvimento profissional. Os Promotores de Justiça, como agentes éticos, podem desempenhar seus papeis de muitas formas. A formação de Promotores, além dos requisitos profissionais, deve incluir a educação da importância do estabelecimento de uma relação de confiança com o cliente.

Palavras-chave: Ética. Moral. Regra Legal. Ministério Público. 


\section{REFERENCES}

From Wikipedia;

Wikipedia -- The term is derived from the Latin "to swear (an oath)". The oath referred to dictates adherence to ethical standards, which invariably include practitioner / client confidentially, truthfulness, and the striving to be an expert in one's calling, all three of these being practiced above all for the benefit of the client. There is also a stipulation about upholding the good name of the profession;

\section{From Black's Law Dictionary;}

Etzoini, ahead;

The ethics of Teaching: Responding Constructively to Complex Situations by Miriam Rosalyn Diamond;

WordNet (R) 1.6, (C) 1997 Princeton University;

The American Heritage (R) Dictionary of the English Language, Fourth Edition, Copyright (C) 2000 by Houghton Mifflin Company;

American Association of University Professors "Statement on Professional Ethics" 1987;

New Directions in Teaching and Learning, 1997 Vol.66;

Marilla Svincki at U.T. Austin;

PLD 1972 SC 139;

Holy Quran; 